NBER WORKING PAPER SERIES

\title{
THE COLLECTION EFFICIENCY OF THE VALUE ADDED TAX: THEORY AND INTERNATIONAL EVIDENCE
}

\author{
Joshua Aizenman \\ Yothin Jinjarak \\ Working Paper 11539 \\ http://www.nber.org/papers/w11539
NATIONAL BUREAU OF ECONOMIC RESEARCH 1050 Massachusetts Avenue
Cambridge, MA 02138
August 2005

The views expressed herein are those of the author(s) and do not necessarily reflect the views of the National Bureau of Economic Research.

(C2005 by Joshua Aizenman and Yothin Jinjarak. All rights reserved. Short sections of text, not to exceed two paragraphs, may be quoted without explicit permission provided that full credit, including (C) notice, is given to the source. 
The Collection Efficiency of the Value Added Tax: Theory and International Evidence Joshua Aizenman and Yothin Jinjarak

NBER Working Paper No. 11539

August 2005

JEL No. F15, H21

\section{ABSTRACT}

This paper evaluates the political economy and structural factors explaining the collection efficiency of the Value Added Tax [VAT]. We consider the case where the collection efficiency is determined by the probability of audit and by the penalty on underpaying. Implementation lags imply that the present policy maker determines the efficiency of the tax system next period. Theory suggests that the collection efficiency is impacted by political economy considerations - greater polarization and political instability would reduce the efficiency of the tax collection. In addition, collection is impacted by structural factors affecting the ease of tax evasion, like the urbanization level, the share of agriculture, and trade openness. Defining the collection efficiency of the VAT as the ratio of the VAT revenue to aggregate consumption divided by the standard VAT rate, we evaluate the evidence on VAT collection efficiency in a panel of 44 countries over 1970-99. The results are consistent with the theory - a one standard deviation increase in durability of political regime, and in the ease and fluidity of political participation, increase the VAT collection efficiency by $3.1 \%$ and $3.6 \%$, respectively. A one standard deviation increase in urbanization, trade openness, and the share of agriculture changes the VAT collection efficiency by $12.7 \%$, 3.9\%, and - 4.8\%, respectively. In addition, a one standard deviation increase in GDP/Capita increases the tax efficiency by $8.1 \%$. Qualitatively identical results apply for an alternative measure of VAT collection efficiency, defined by the ratio of VAT revenue to GDP divided by the standard VAT.

Joshua Aizenman

Economics Department, E2

UCSC, Santa Cruz

Santa Cruz, CA 95060

and NBER

jaizen@ucsc.edu
Yothin Jinjarak

Division of Economics, HSS

Nanyang Technological University

S3-B2A-38 Nanyang Avenue

SINGAPORE 637698

yjinjarak@ntu.edu.sg 
GROWING numbers of policy analysts and politicians are saying that it may finally be time to consider a value-added tax as part of our federal revenue system. In years past, I would have been in the forefront of those denouncing the idea... the main reason for this is that it was too easy to raise V.A.T. rates amid the double-digit price increases of the inflationary 1970 's. In those days, there were many economists who still believed that budget deficits caused inflation, making it easier to delude people into thinking that higher taxes were necessary to get inflation under control...Those countries that adopted the value-added tax since the end of the great inflation, however, have been very restrained in raising rates... But unless spending is checked or revenue raised, we are facing deficits of historic proportions... When that day comes, huge tax increases are inevitable because no one has the guts to seriously cut health spending. Therefore, the only question is how will the revenue be raised: in a smart way that preserves incentives and reduces growth as little as possible, or stupidly by raising marginal tax rates and making everything bad in our tax code worse? If the first route is chosen, the value-added tax is by far the best option available to deal with an unpalatable situation.

From “Feed the Beast, Republicans are the problem,” New York Times April 6, 2005, Bruce Bartlett

The globalization of trade and finance has profound implications on the patterns of taxes. Developing countries used to rely heavily on trade taxes, seigniorage and financial repression as the main sources of fiscal revenue. A common denominator of these taxes is that they are associated with a relatively low cost of collection and enforcement - trade taxes are collected at a centralized port of entry, and seigniorage and financial repression act as an implicit tax. Greater trade integration has implied a drastic cut in tariffs, reducing thereby the revenue of trade taxes. Successful macro stabilizations and greater financial openness sharply reduced the revenue from seigniorage and financial repression. ${ }^{1}$ While most of these developments enhanced efficiency, they also exposed developing countries to the challenge of finding alternative means of financing fiscal needs.

Most countries dealt with the new challenges by adopting new taxes, including the Value Added Tax [VAT]. Today, the VAT is a major part of the tax system in over 136 countries, raising about one-fourth of the world's tax revenue [Ebrill, Keen, Bodin, and Summers (2001, 2002)]. The debate regarding the welfare gains associated with switching from trade taxes to the VAT is not over. Emran and Stiglitz (2005) cautioned that the welfare gains from a switch to the VAT are questionable in the presence of a large informal sector. Baunsgaard and Keen (2005) found that for middle-income countries, revenue recovery following trade liberalization has been about 50 cents for each dollar of lost trade tax revenue, and the revenue recovery has been very weak in low-income countries. Nor is there much evidence that the mere presence of a valueadded tax has made it easier to cope with the revenue effects of trade liberalization. As the lead

\footnotetext{
${ }^{1}$ The greater de-facto financial integration may be either the outcome of policy choice [de-jure financial integration], or a by product of greater trade openness, forcing greater de-facto financial openness [see Prasad, Rogoff, Wei and Koss (2003), Aizenman (2004) and Aizenman and Noy (2005)]. See Gordon and Li (2005) and Jinjarak (2005) for tax collection challenges facing developing countries.
} 
citation points out, adopting the VAT also remains a debated issue in the USA, framed occasionally as "A too easy tax to collect" by advocates of the "Starve the beast" approach to government's size, versus views that focus on the welfare cost of alternative taxes.

A frequently cited advantage of the VAT is that this tax is collected throughout the production chain, giving it a practical advantage. ${ }^{2}$ Specifically, the VAT should be associated with easier enforcement, as it allows the fiscal authority to compare reported sales of each intermediate product with reported purchases of producers using that intermediate product as an input in a vertical production chain. While the VAT may indeed be an easier tax to enforce than income tax, the VAT is not a panacea - enforcing it involves spending resources on collecting and processing information, prosecuting and penalizing agents found underpaying the tax, etc. Hence, one expects that VAT collection efficiency increases with the resources spent on enforcement, and with the efficiency of monitoring, collecting and processing information. Theory suggests that the enforceability of taxes is impacted by political economy considerations - greater polarization and political instability would tend to reduce the efficiency of tax collection, reducing the resources devoted to tax enforcement. In addition, collection is impacted by structural factors that affect the ease of tax evasion, like the urbanization level, the share of agriculture, and trade openness.

The purpose of this paper is to verify the dependence of VAT collection efficiency on key structural and political economy factors. Section 2 outlines a model determining VAT efficiency, extending Cukierman, Edwards and Tabellini (1992). Specifically, we model the optimal tax evasion of agents, in an economy where the government determines optimally the probability of audit and the penalty associated with underpaying the VAT. We show that greater political instability and polarization tends to reduce tax efficiency. Similarly, economic structures that increase the cost of enforcement, like less urbanization, less trade openness, and higher share of agriculture, reduce the collection efficiency of the VAT.

Section 3 confirms these predictions in a study that explains two measures of VAT collection efficiency. The first, dubbed C-efficiency, is the ratio of the VAT revenue to aggregate consumption, divided by the standard VAT rate. The second is the ratio of VAT

\footnotetext{
${ }^{2}$ See Gordon and Nielsen (1997) for an assessment of the gains associated with the switch to the VAT.
} 
revenue to GDP, divided by the standard VAT rate. ${ }^{3}$ The closer these ratios are to zero (one), the lower (higher) the collection efficiency of the VAT tax. Having information on the standard VAT rate in 2003 for a sample of 44 countries, we assume that the statutory rates do not change frequently in practice, and use information about the annual VAT revenues, economic and political variables of the 44 countries over the period 1970-1999. During this sample period, the collection efficiency of VAT ranges from 2.4 percent in Belarus, 9.6 percent in Mexico, to 45.2 percent in Finland. The data also suggest a wide range of VAT experiences. There is no systematic difference in statutory VAT rates between high-income and developing countries. The size of VAT revenue as a percentage of total tax revenue varies from 6.6 percent in Japan, to 40.5 percent in Chile. VAT revenue to GDP ranges from 0.1 percent in Guinea to 10 percent in Norway. Across countries, VAT revenues to GDP increase with real GDP per capita, and urbanization share of population, and decreases with agriculture share of GDP.

The main findings reported in Section 3 are that political economy and structure matter in ways consistent with the theory. The effects are economically and statistically significant. A one standard deviation increase in durability of political regime, and in the ease and fluidity of political participation, increase the first VAT collection efficiency measure (C-efficiency) by 3.1 percent and 3.6 percent, respectively. A one standard deviation increase in urbanization, trade openness, and the share of agriculture changes the VAT collection efficiency by 12.7 percent, 3.9 percent, and - 4.8 percent, respectively. In addition, a one standard deviation increase in the GDP/Capita increases the tax efficiency by 8.1 percent. Qualitatively identical results apply for the alternative measure of VAT collection efficiency. Section 4 closes the paper with concluding remarks.

\section{The model}

Our benchmark model is adopted from Cukierman, Edwards and Tabellini (1992), which explains the obstacles to tax reforms in polarized countries, characterized by political instability. They focused on the case where fiscal revenue can be raised by taxes associated with collection costs [like income taxes], and implicit taxes where the collection cost is zero, like the inflation

\footnotetext{
${ }^{3}$ See Ebrill et. al. (2001) for a detailed discussion of these two measures of VAT collection efficiency. They point out that the appropriate benchmark for the VAT should be total consumption (being the ideal VAT base, exempting investment), and not GDP. In addition, GDP may be subject to greater measurement error than consumption.
} 
tax. They assumed implementation lags - the present policy maker determines the efficiency of the tax system next period. This implies that the choice of the tax system efficiency may be strategic - the current policy maker may choose an inefficient future tax system in order to constrain the fiscal revenue available to future policy makers. This prevents future policy makers from spending in ways that are viewed as inferior from the vantage point of the present policy maker.

The economy at time $t$ is described by two representative budget constraints: the government, (1) and the private sector, (2):

$$
\begin{aligned}
& g_{t}+f_{t}+\theta_{t} \leq \tau_{t}^{a}+s_{t} \\
& c_{t}=1-\tau_{t}^{a}-s_{t}-\delta\left(\tilde{\tau}_{t}\right)-\gamma\left(s_{t}\right) .
\end{aligned}
$$

Each individual is endowed with one unit of output in each period. The variables $g_{t} ; f_{t}$ represent two different public goods [say guns and butter] in per capita terms, and $c_{t}$ is percapita private consumption. The term $\theta_{t}$ is the fiscal investment in tax capacity, the impact of which is discussed below. The government collects from each individual an amount $s_{t}$, in the form of seigniorage, and an amount $\tau_{t}^{a}$ of actual VAT revenue. The statutory VAT rate is $\tilde{\tau}_{t}$. Seigniorage carries no administrative costs, whereas the VAT is associated with costly enforcement, described below. Both VAT and seigniorage impose convex deadweight losses on the private sector, equal to $\delta\left(\tilde{\tau}_{t}\right) ; \gamma\left(s_{t}\right)$, satisfying $\delta^{\prime}>0, \quad \delta^{\prime \prime}>0, \gamma^{\prime}>0, \quad \gamma^{\prime \prime}>0$.

\section{The agent's problem}

Underpaying the VAT is costly: with probability $p_{t}$, the agent is audited. If she is found paying $\tau_{t}$ below the statutory rate, she would be penalized, paying $\tilde{\tau}_{t}+0.5 \phi_{t}\left[\tilde{\tau}_{t}-\tau_{t}\right]^{2}$. Hence, underpaying is associated with a quadratic penalty of $0.5 \phi_{t}\left[\tilde{\tau}_{t}-\tau_{t}\right]^{2}$, paid with probability $p_{t}$. 
The period t utility from the private consumption is $U\left(c_{t}\right)$. The representative agent would submit tax payment $\tau_{t}^{s}$, maximizing her expected utility:

$$
\operatorname{MAX}\left[p_{t} U\left(c_{t, a}\right)+\left(1-p_{t}\right) U\left(c_{t, n}\right)\right]
$$

$\tau_{t}$

where $c_{t, a}\left(c_{t, n}\right)$ is the agent's private consumption at time t if she is audited (not audited):

$c_{t, a}=1-\left\{\tilde{\tau}_{t}+0.5 \phi_{t}\left[\tilde{\tau}_{t}-\tau_{t}\right]^{2}\right\}-s_{t}-\delta\left(\tilde{\tau}_{t}\right)-\gamma\left(s_{t}\right)$

$c_{t, n}=1-\tau_{t}-s_{t}-\delta\left(\tilde{\tau}_{t}\right)-\gamma\left(s_{t}\right)$

Optimizing (3), the optimal submitted tax, denoted by $\tau_{t}^{s}$, is:

$$
\tau_{t}^{s}=\tilde{\tau}_{t}-\frac{1-p_{t}}{p_{t} \phi_{t}}(1-\lambda)
$$

where $\lambda$ is the risk premium adjustment, $\lambda=\frac{U^{\prime}\left(c_{t, a}\right)-U^{\prime}\left(c_{t, n}\right)}{U^{\prime}\left(c_{t, a}\right)} \geq 0$, and $U^{\prime}\left(c_{t}\right)$ is the marginal utility associated with consumption $c_{t}$. The risk term, $\lambda$, is the percentage gap of the marginal utilities between the audit and no-audit cases. The resultant expected tax payment is

$$
E\left[\tau_{t}\right]=\tilde{\tau}_{t}-0.5 \frac{\left(1-p_{t}\right)^{2}}{p_{t} \phi_{t}}\left(1-\lambda^{2}\right)
$$

The expected tax payment increases with the probability of an audit, and with the penalty rate associated with underpayment. It also increases with the degree of risk aversion - higher risk aversion increases the utility cost associated with being audited. In practice, the risk adjustment term, $\lambda$, is of second order magnitude in circumstances where the tax gap between the increases 
in tax payment associated with audit, is small relative to total consumption. Thus, for simplicity, we henceforth ignore this risk adjustment term, assuming $\lambda \cong 0{ }^{4}$

The economy is populated with a large number of atomistic agents. Hence, from the point of view of the authorities, the idiosyncratic risk associated with tax evasion is diversified away - in the macro budget constraints (1) - (2), the actual tax revenue $\tau_{t}^{a}$ is the expected tax payment of the atomistic agent,

$$
\tau_{t}^{a}=\tilde{\tau}_{t}-0.5 \frac{\left(1-p_{t}\right)^{2}}{p_{t} \phi_{t}}\left(1-\lambda^{2}\right) \cong \tilde{\tau}_{t}-0.5 \frac{\left(1-p_{t}\right)^{2}}{p_{t} \phi_{t}}
$$

\section{The policy maker problem}

There are two possible policymaker types, $\mathrm{L}$ and $\mathrm{R}$, who randomly alternate in office. The policy maker of type i, i = L, R maximizes welfare:

$$
w_{i}^{t}=E_{t}\left\{\sum_{k=0}^{\infty} \beta^{k}\left[U\left(c_{t+k}\right)+H^{i}\left(g_{t+k}, f_{t+k}\right)\right]\right\} ; 1>\beta>0
$$

where $E_{t}$ denotes the expectation operator, $U$ is a concave utility function. The utility from consuming $g$ and $f, H^{i}$, is defined as follows,

$$
\begin{array}{ll}
H^{L}(g, f)=\left(\frac{1}{\alpha(1-\alpha)}\right) \min [\alpha g,(1-\alpha) f] ; & 1>\alpha>0 \\
H^{R}(g, f)=\left(\frac{1}{\alpha(1-\alpha)}\right) \min [(1-\alpha) g, \alpha f] ; &
\end{array}
$$

${ }^{4}$ It is easy to verify that $\lambda \cong \frac{c_{t, n}-c_{t, a}}{c_{t, a}} \frac{-U^{\prime \prime}\left(c_{t, a}\right)}{U^{\prime}\left(c_{t, a}\right)}$. Hence, $\lambda$ is negligible when $\frac{c_{t, n}-c_{t, a}}{c_{t, a}}$ is small. Note that audit risk is idiosyncratic, and may be diversified away by distributing it across agents. The risk adjustment would be zero in the presence of such insurance. Our analysis can be extended to the case where the risk adjustment factor is positive, without impacting the main results. 
Thus, the two policy makers differ only in the desired composition of the public good, where their disagreement is parameterized by $|\alpha-0.5|$. By construction, the overall weight given to private versus public consumption, does not depend on the disagreement parameter, $\alpha$.

The political system is described as a Markov process with transition probabilities $\pi$ and $1-\pi$ : the government in office at time thas a fixed probability $1-\pi$ of being reappointed next period. With probability $\pi$, it is thrown out of office and the other policymaker type is appointed.

Let $x \equiv g+f$ denote the total amount of government spending. For concreteness, we assume $\alpha>0.5$. While the private agent views the probability of an audit, and the penalty rate at time $t$, as exogenous, these variables are pre-determined by the policy maker at time $t-1$. The efficiency of the tax system is determined by the probability of an audit, and by the penalty associated with tax evasion, $p$ and $\phi$, respectively. We assume that both $p$ and $\phi$ are determined by the investment in tax capacity, $\theta$. To capture the greater inertia in reforming the tax system than in changing fiscal policy, assume that the investment in tax efficiency, $\theta$, along with $p$ and $\phi$, but not the other policy variables $\left(\tilde{\tau}_{t} ; s_{t} ; g_{t} ; f_{t}\right)$, must be chosen one period in advance. Thus, $\theta_{t-1}$ was chosen at time t-1, but exerts an influence on the efficiency of the tax system only at time t:

$$
\begin{aligned}
p_{t} & =p_{t}\left(\theta_{t-1} ; S T\right) ; \quad p^{\prime}>0 ; \quad p^{\prime \prime}<0 ; \\
\phi_{t} & =\phi_{t}\left(\theta_{t-1} ; S T\right) ; \quad \phi^{\prime}>0 ; \quad \phi^{\prime \prime}<0 ;
\end{aligned} .
$$

where $S T$ is the vector of structural factors impacting the cost of tax collection. Specifically, high urbanization rate, lower share of agriculture and higher trade openness may reduce the effective cost of monitoring and collecting information, implying greater efficiency of the collection system. As these structural factors are changing slowly, we view them beyond the control of the policy maker, and focus on the determination of optimal investment in tax capacity, $\theta_{t}$.

Our system differs from the one in Cukierman et. al (1992) in two ways: we model the tax aversion and the auditing process, and we assume that improving the efficiency of the tax 
system at time $t$ involves a costly investment at time $t-1$. Despite these modifications, the solution methodology of Cukierman et. al (1992) continues to apply. As in proposition 1 in Cukierman et. al. (1992), optimal choices of consumption, aggregate public good, seigniorage and VAT are a function of the efficiency of the tax system:

$$
c^{*}=C(\theta) ; x^{*}=X(\theta) ; s^{*}=S(\theta) ;\left(\tau^{a}\right)^{*}=T(\theta)
$$

satisfying $C^{\prime}(\theta)<0 ; X^{\prime}(\theta)>0 ; S^{\prime}(\theta)<0 ; T^{\prime}(\theta)>0$, where $z^{*}$ denotes the optimal value of $z$. The equilibrium value of the tax rate chosen, $\theta$, satisfies the first order condition: ${ }^{5}$

$$
\beta U^{\prime}(C(\theta)) C^{\prime}(\theta)+\left[1-\pi+\pi \frac{1-\alpha}{\alpha}\right] X^{\prime}(\theta)=1
$$

The main results of the model are summarized in a proposition akin to proposition 2 in Cukierman at. al (1992):

I. If the current government is certain of being reappointed, or if there is no polarization ( $\pi=0$ or $\alpha=0.5$ ), then it brings about the most efficient tax system. The corresponding FOC is $\beta U^{\prime}(C(\theta)) C^{\prime}(\theta)+X^{\prime}(\theta)=1$.

II. The lower the probability that the current government will remain in office and the greater the polarization, the more inefficient is the tax system left as a legacy to the future administration. This inefficiency is manifested by lower investment in tax capacity, inducing a lower probability of auditing, and a lower penalty on tax evasion,

\footnotetext{
${ }^{5}$ As in Cuikerman et. al. (1992), since the tax capacity is set one period in advance, and is reset each period, the infinite horizon equilibrium is characterized by looking one period ahead. The symmetry of the specification implies that the policy maker at time $\mathrm{t}$ is setting the tax capacity for the next period, $\theta$, by maximizing $\beta\left\{U(C(\theta))+\left[1-\pi+\pi \frac{1-\alpha}{\alpha}\right] X(\theta)\right\}-\theta$. The term $\beta\left\{U(C(\theta))+\left[1-\pi+\pi \frac{1-\alpha}{\alpha}\right] X(\theta)\right\}$ is the discounted expected utility of the policy maker next period, recognizing that the equilibrium private consumption does not depend on the identity of the regime, and that the policy maker is reappointed [losing power] with probability $1-\pi[\pi]$, enjoying utility from fiscal consumption of $X(\theta)\left[\frac{1-\alpha}{\alpha} X(\theta)\right]$, respectively. The second term, $-\theta$, is the present resource cost of the fiscal investment in future tax capacity, reducing the present fiscal consumption enjoyed by the decision maker.
} 
reducing thereby the tax collection associated with a given statutory VAT rate. Structural factors that increase the ease of tax evasion reduce the equilibrium tax collection.

\section{The evidence}

As of 2004, 136 countries have implemented a VAT (International Tax Dialogue, 2005). About one-third of these countries has complete information on annual VAT revenues, and corresponding economic, structural, and political variables in those years. Table 1 reports statutory VAT rates, and averages of the actual VAT revenues over 1970-1999, for these 44 countries for which data are available. Because we only have access to the last year of crosscountry information on statutory VAT rates, our investigation is forced to use VAT rates as of the year 2003. Nevertheless, the VAT rates do not change frequently over time. Due to these data limitations, we end up with a total of 454 observations.

In the sample, the earliest implementation of the VAT was by Brazil in 1967, and the latest by Cameroon in 1999. ${ }^{6}$ There is no systematic difference in statutory VAT rates between high-income and developing countries. The size of VAT revenue in total tax revenue varies from 6.6 percent in Japan to 40.5 percent in Chile. Figure 1 relates cross-country VAT revenue to a set of economic variables. VAT revenue to GDP tends to increase with real GDP per capita, and urbanization share of population, and decrease with the agriculture share of GDP. To answer how this cross-country variability can be explained by economic variables, we estimate panel linear equations of VAT collection efficiency controlling for a set of explanatory variables suggested in the literature.

We calculate VAT collection efficiency using two alternatives: (i) C-efficiency ratio, defined as annual VAT revenue to consumption divided by the year 2003 standard VAT rate; (ii) Efficiency ratio, defined as annual VAT revenue to GDP divided by the year 2003 standard VAT rate. The difference between the two alternatives is that the C-efficiency ratio is normalized by reference to a consumption-type VAT, whereas the Efficiency ratio is normalized by reference to an income-type VAT.

The explanatory variables are:

\footnotetext{
${ }^{6}$ France was the first to implement a VAT in 1948. Cape Verde recently implemented a VAT in 2004. Due to data limitations, these two countries were excluded from the sample.
} 
(a) Measures of economic development: real GDP per capita. We expect that a higher level of income should be associated with higher VAT collection efficiency.

(b) Composition of gross domestic product and population: agricultural share in GDP, trade openness, and urbanization of population. We expect that it is more difficult to administer and collect a VAT in less urbanized, more rural countries. We also include trade to GDP since imports are an important base for VAT, and represent the part of the VAT that is more easily enforced. ${ }^{7}$

(c) Measures of political instability and fluidity of political participation: durability of political regime, and regulation of political participation. We expect higher VAT performance in countries with a more stable political regime and highly regulated political participation (hence, more homogeneous societies with relatively fluid political participation), than less stable, more polarized political systems.

The Data Appendix provides sources and details of these variables.

Table 2 reports the results for the two alternative measures of VAT collection efficiency. To handle both the time and cross-country dimension of the data, we employ fixed-effects estimation including year dummies. The dependent variable for the first three columns is the Cefficiency ratio, and for the last three columns the Efficiency ratio. Using the C-efficiency ratio as a measure of VAT performance (columns I-III), all of the coefficient estimates have the expected sign. Urbanization, trade openness, real GDP per capita, and measures of political stability and fluidity if political participation, enter positively, indicating that VAT collection efficiency is increasing in these variables. In addition, a higher agriculture share of GDP is associated with a significantly lower VAT performance. Furthermore, these explanatory variables are robust to various specifications. Columns IV-VI, with the Efficiency ratio as the dependent variable, yield similar results. One exception is the urbanization of population, which has the expected sign, but is not statistically significant.

These regressions account for 55-67 percent of the variance in the data. Figure 2 summarizes the contribution of the explanatory variables in regressions III and VI. The economic significance of these variables is sizable. The two most important variables explaining the VAT performance are the urbanization share of population, and real GDP per capita. A one standard 
deviation increase in the urbanization share (18.1 percent of the total population) raises the VAT C-efficiency ratio by 12.7 percent, and the Efficiency ratio by 4.4 percent. A one standard deviation increase in per capita GDP (US\$5,960) raises the C-efficiency ratio by 8.1 percent and the Efficiency ratio by 4.6 percent. A one standard deviation increase in trade openness raises the C-efficiency ratio by 3.9 percent, and the Efficiency ratio by 1.7 percent. A one standard deviation increase in the GDP share of agriculture reduces the C-efficiency ratio by 4.8 percent, and the Efficiency ratio by 3.5 percent. Political economy variables also provide significant explanation of the VAT performance. A one standard deviation increase in the durability of the political regime, and in the regulation of political participation, raise the VAT C-efficiency by 3.1 percent and 3.6 percent, respectively. Similar results apply to the impact of political economy variables on VAT measured by the Efficiency ratio.

Tables 3 and 4 report robustness checks of our main results. In columns VII and VIII of Table 3, we added the age of the VAT (years since first implemented) to the regressions to capture how the maturity of the VAT may influence its collection efficiency. The age of the VAT has an unexpected negative sign, but it is insignificant and provides essentially no explanatory power to the regressions of VAT performance. Ebrill et. al. (2001) found weak support for the role of VAT age in collection efficiency. One interpretation is that while administration of, and compliance with the VAT, may improve with experience, the structural and political factors of the economy are more important considerations. Indeed, we continue to find economically significant effects of the main explanatory variables in our benchmark regressions of Table 2.

In the last four columns of Table 3 we check whether the association between VAT collection efficiency, and its determinants, differs between high-income and developing countries. Columns IX and X refer to high-income countries in the sample. The last two columns refer to developing countries only. For the developing countries, all of the coefficient estimates continue to have the expected sign and economic significance. Contrast this with the result that only real GDP per capita, and agriculture share of GDP have explanatory power when considering VAT collection efficiency in the high-income group. It is possible to interpret this result as supporting the hypothesis that collection costs and political instability are likely to be

\footnotetext{
${ }^{7}$ See Fisman and Wei (2004) for empirical evidence on the enforcement problem dealing with tax evasion and imports.
} 
more important to VAT performance in developing countries, than in high-income countries. Alternatively, the variation in the political economy variable, among the high income countries, is not sizable enough to matter for explaining the tax efficiency. It is also possible that given the importance of, and difference in, the level of financial openness across countries, the actual implementation of a VAT on financial services involves different problems in developing countries, than exist in high-income countries (on taxation of financial services under a VAT, see Auerbach and Gordon, 2002).

Table 4 reports cross-country OLS regressions, which, given data limitations, allow us to explore the association between VAT collection efficiency and income inequality. The crosscountry sample is an average over the period 1970-1999, covering 40 countries. In a crosscountry context, income level, as measured by real GDP per capita, is highly correlated with other explanatory variables (-0.69 with the agriculture share; 0.68 with the durability of political regime; -0.50 with the GINI index). Columns XIV and XVI provide the explanatory power of the main structural, political, and income inequality variables, on VAT performance. As in the panel estimation, the effects of the agriculture share and the durability of political regime continue to be sizable and the cross-country regressions account for 59 percent -61 percent of the variance in the data. A one standard deviation increase in the former is associated with 5.15 percent (9.3 percent) reduction in VAT Efficiency (C-efficiency). An additional year of continuing political regime is associated with a 0.31 percent increase in VAT performance. Income inequality, as measured by the GINI coefficient, enters the regressions negatively and is statistically significant: a one standard deviation increase in the GINI is associated with 2.53 percent (4.43 percent) reduction in the collection efficiency of VAT revenue as a percentage of GDP (of consumption).

\section{Concluding remarks}

The evidence presented in this paper is consistent with the structural, political economy approach to taxation. While our paper does not negate the possibility of efficiency gains associated with greater reliance on a VAT, it points out that these gains are not automatic, and may depend on structural factors. We close the paper with a discussion of limitations and future research. Our analysis focused on the de-facto efficiency of a VAT. A limitation of this concept is that it is impacted by both tax evasion, and statutory exemptions from VAT (like 
allowing for lower tax rates on some categories). The absence of detailed information prevents us at this stage from a more detailed decomposition of the de-facto collection efficiency between tax evasion and statutory exemptions. Similarly, we assumed limited time variation in the standard VAT in each country. Better data should allow us to improve the precision of the empirical part. Despite these data limitations, our empirical investigation supports the prediction of a political economy, public finance approach to taxation. This approach may be useful in addressing the design and use of other taxes, including income, sales and trade taxes. Identifying the trade-offs between a VAT and other taxes remains a topic worthy of future research. 


\section{References}

Aizenman, J. (2004). "Financial Opening and Development: Evidence and Policy Controversies," American Economic Review, vol. 94(2), 65-70.

Aizenman J. and I. Noy (2004). “Endogenous financial and trade openness: efficiency and political economy considerations,” manuscript, UCSC.

Auerbach, A. J. and R. H. Gordon (2002). "Taxation of Financial Services under a VAT," American Economic Review, vol. 92(2), 411-416.

Baunsgaard T. and M. Keen (2005). “Tax Revenue and (or?) Trade Liberalization,” IMF $\mathrm{WP} / 05 / 112$.

Cukierman, A., S. Edwards, and G. Tabellini (1992): "Seigniorage and Political Instability," American Economic Review, 82, 537-555.

Ebrill, L., M. Keen, J-P. Bodin, and V. Summers (2001). The Modern VAT (Washington: International Monetary Fund). (2002). “The Allure of the Value-Added Tax,” Finance and Development, June, Vol. 39, 2.

Emran, M. S. and J. E. Stiglitz (2005). “On Selective Indirect Tax Reform in Developing Countries,” Journal of Public Economics, Vol. 89 (April), pp. 599-623.

Fisman, R. and S.-J. Wei. 2004. “Tax Rates and Tax Evasion: Evidence from 'Missing Imports' in China,” Journal of Political Economy. 112(2):471-496.

Gordon R. and W. Li (2005). “Tax Structure in Developing Countries: Many Puzzles and a Possible Explanation,” NBER WP 11267.

Gordon, R. H. and S. B. Nielsen (1997). “Tax evasion in an open economy: Value-added vs. income taxation,” Journal of Public Economics, 66, 173-197. 
International Tax Dialogue (2005). “The Value Added Tax: Experiences and Issues.” Background paper, prepared for the VAT conference in Rome, March 15-16.

Jinjarak Y. (2005). Adios Government Revenue from Financial Repression: More on the Consequences of Financial and Trade Opening, manuscript, Nanyang Technological University (NTU).

Prasad, E., K. Rogoff, S. J. Wei and M. A. Koss (2003). “Effects of Financial Globalization on Developing Countries: Some Empirical Evidence,” IMF Working Paper, March 2003.

PricewaterhouseCoopers, LLP (2004). Corporate Taxes: Worldwide Summaries. Vol. 20032004. John Wiley \& Sons, Inc. 


\section{Data Appendix}

$\begin{array}{ll}\text { Abbreviations and Acronyms } \\ \text { GDP } & \text { Gross Domestic Product } \\ \text { POLITY } & \text { POLITY IV project } \\ \text { PWC } & \text { PricewaterhouseCoopers } \\ \text { PWT } & \text { Penn World Table 6.1 } \\ \text { VAT } & \text { Value Added Tax } \\ \text { WDI } & \text { World Development Indicators }\end{array}$

The sample comprises 44 countries over the period 1970-1999. There are 454 observations. The list of countries and number of years observed are in Table 1. Because we only have access to the latest cross-country information on statutory VAT rates, the panel estimation is forced to use VAT rates as of 2003. In practice, the VAT rates do not change frequently over time.

Statutory VAT rates: Cross-country standard rates as of 2003.

Source: PWC “Corporate Taxes, worldwide summaries 2003-2004”

\section{Year VAT introduced}

Source: International Tax Dialogue (2005)

\section{VAT revenue, Total tax revenue}

Source: "World Tax Database” from the Office of Tax Policy Research, University of Michigan. http://www.bus.umich.edu/OTPR

VAT C-efficiency ratio: VAT revenue to consumption divided by the 2003 standard VAT rate; percent.

VAT Efficiency ratio: VAT revenue to GDP divided by the 2003 standard VAT rate; percent.

Real GDP per capita: A chain GDP; US $\$ 1,000$.

Source: PWT; http://pwt.econ.upenn.edu/

Trade Openness: Exports plus imports divided by GDP; percent. Source: PWT

Agriculture share of GDP: value added (percent of GDP). Agriculture corresponds to ISIC divisions 1-5 and includes forestry, hunting, and fishing, as well as cultivation of crops and livestock production. Value added is the net output of a sector after adding up all outputs and subtracting intermediate inputs. It is calculated without making deductions for depreciation of fabricated assets or depletion and degradation of natural resources. The origin of value added is determined by the International Standard Industrial Classification (ISIC) revision 3. Source: WDI (from World Bank national accounts data, and OECD National Accounts data files); http://www.worldbank.org/data/onlinedatabases/onlinedatabases.html

Urbanization of population: Urban population (percent of total). Urban population is the share of the total population living in areas defined as urban in each country. 
Source: WDI (from United Nations, World Urbanization Prospects).

Durability of Political Regime: The number of years since the most recent regime change (defined by a three-point change in the POLITY score over a period of three years or less) or the end of a transition period defined by the lack of stable political institutions (denoted by a standardized authority score). The first year during which a new (post-change) polity is established is coded as the baseline "year zero" (value $=0$ ) and each subsequent year adds one to the value of the variable consecutively until a new regime change or transition period occurs. Values are entered for all years beginning with the first regime change since 1800 or the date of independence if that event occurred after 1800.

Source: POLITY; http://www.cidcm.umd.edu/inscr/polity/

Regulation of Political Participation: Participation is regulated to the extent that there are binding rules on when, whether, and how political preferences are expressed. One-party states and Western democracies both regulate participation but they do so in different ways, the former by channeling participation through a single party structure, with sharp limits on diversity of opinion; the latter by allowing relatively stable and enduring groups to compete nonviolently for political influence. The polar opposite is unregulated participation, in which there are no enduring national political organizations, and no effective regime controls on political activity. In such situations political competition is often characterized by recurring coercion among shifting coalitions of partisan groups. The index ranges from 1 to 5 :

$1=$ unregulated. Political participation is revolving around personalities, regional interests, and religious/ethnic/clan groups; but the number and relative importance of such groups in national political life varies substantially over time. There are no enduring national political organizations and systematic regime control of political activity is limited, that is, a situation characterized by a coincidence of a weak state and society. These conditions are increasingly rare following decolonization and the increasing globalization of economic exchange systems. In the contemporary context, uninstitutionalized competition is most likely to occur in resource poor countries and/or following the collapse of central authority under a (former) repressive, authoritarian state. 5 = regulated. Relatively stable and enduring political groups regularly compete for political influence and positions with little use of coercion. No significant groups, issues, or types of conventional political action are regularly excluded from the political process. Source: POLITY

GINI index: Gini index measures the extent to which the distribution of income (or, in some cases, consumption expenditure) among individuals or households within an economy deviates from a perfectly equal distribution. A Lorenz curve plots the cumulative percentages of total income received against the cumulative number of recipients, starting with the poorest individual or household. The Gini index measures the area between the Lorenz curve and a hypothetical line of absolute equality, expressed as a percentage of the maximum area under the line. Thus a Gini index of 0 represents perfect equality, while an index of 100 implies perfect inequality. World Bank staff estimates are based on primary household survey data obtained from government statistical agencies and World Bank country departments.

Source: WDI 
Table 1. VAT: rates and revenues

\begin{tabular}{|c|c|c|c|c|c|}
\hline \multirow[b]{2}{*}{ Country } & \multirow[b]{2}{*}{$\begin{array}{l}\text { Year VAT } \\
\text { Introduced }\end{array}$} & \multirow[b]{2}{*}{$\begin{array}{r}\text { Statutory } \\
\text { VAT Rates } \\
\text { as of } 2003\end{array}$} & \multicolumn{2}{|c|}{ VAT Revenue } & \multirow[b]{2}{*}{$\begin{array}{c}\text { Number of } \\
\text { Observation }\end{array}$} \\
\hline & & & $\begin{array}{r}\text { percentage of } \\
\text { GDP }\end{array}$ & $\begin{array}{r}\text { percentage of } \\
\text { total tax } \\
\text { revenue }\end{array}$ & \\
\hline Albania & 1996 & 20.0 & 1.3 & 34.6 & 3 \\
\hline Argentina & 1975 & 21.0 & 1.9 & 21.5 & 11 \\
\hline Azerbaijan & 1992 & 18.0 & 0.5 & 16.0 & 6 \\
\hline Belarus & 1992 & 18.0 & 0.4 & 19.6 & 8 \\
\hline Belgium & 1971 & 21.0 & 7.5 & 17.6 & 28 \\
\hline Bolivia & 1973 & 14.9 & 1.4 & 33.6 & 15 \\
\hline Brazil & 1967 & 20.5 & 0.9 & 9.2 & 5 \\
\hline Cameroon & 1999 & 18.7 & 1.1 & 27.9 & 1 \\
\hline Canada & 1991 & 7.0 & 2.3 & 13.3 & 7 \\
\hline Chile & 1975 & 19.0 & 4.4 & 40.5 & 25 \\
\hline Colombia & 1975 & 16.0 & 1.2 & 28.7 & 25 \\
\hline Costa Rica & 1975 & 13.0 & 1.7 & 16.6 & 25 \\
\hline Cyprus & 1992 & 15.0 & 2.8 & 16.2 & 3 \\
\hline Estonia & 1992 & 18.0 & 2.9 & 32.1 & 8 \\
\hline Finland & 1994 & 22.0 & 9.9 & 29.7 & 5 \\
\hline Greece & 1987 & 18.0 & 6.1 & 35.8 & 12 \\
\hline Guinea & 1996 & 18.0 & 0.1 & 5.5 & 2 \\
\hline Honduras & 1976 & 12.0 & 0.5 & 7.4 & 6 \\
\hline Hungary & 1988 & 25.0 & 3.4 & 20.1 & 12 \\
\hline Indonesia & 1985 & 10.0 & 0.9 & 21.9 & 15 \\
\hline Italy & 1973 & 20.0 & 4.6 & 15.2 & 26 \\
\hline Japan & 1989 & 5.0 & 1.5 & 6.6 & 5 \\
\hline Korea, Rep. & 1977 & 10.0 & 2.3 & 23.8 & 3 \\
\hline Mauritius & 1998 & 15.0 & 0.9 & 19.9 & 2 \\
\hline Mexico & 1980 & 15.0 & 1.4 & 21.5 & 19 \\
\hline Morocco & 1986 & 20.0 & 1.9 & 24.2 & 10 \\
\hline Nepal & 1997 & 10.0 & 0.4 & 28.0 & 3 \\
\hline Nicaragua & 1975 & 14.0 & 0.6 & 11.8 & 6 \\
\hline Norway & 1970 & 24.0 & 10.6 & 25.5 & 27 \\
\hline Pakistan & 1990 & 15.0 & 0.5 & 15.7 & 10 \\
\hline Panama & 1977 & 5.0 & 0.9 & 8.5 & 15 \\
\hline Paraguay & 1993 & 10.0 & 1.0 & 37.7 & 1 \\
\hline Peru & 1973 & 19.0 & 2.4 & 35.2 & 11 \\
\hline Poland & 1993 & 22.0 & 3.3 & 22.6 & 6 \\
\hline Russian Federation & 1992 & 18.0 & 1.2 & 25.5 & 4 \\
\hline Senegal & 1980 & 17.0 & 1.5 & 18.0 & 5 \\
\hline South Africa & 1991 & 14.0 & 2.8 & 23.9 & 9 \\
\hline Thailand & 1992 & 7.0 & 1.3 & 22.1 & 8 \\
\hline Trinidad and Tobago & 1990 & 15.0 & 2.2 & 20.8 & 3 \\
\hline Tunisia & 1988 & 18.0 & 1.2 & 14.3 & 12 \\
\hline Turkey & 1985 & 18.0 & 1.8 & 28.7 & 14 \\
\hline Uruguay & 1968 & 23.0 & 3.3 & 26.0 & 24 \\
\hline Venezuela, RB & 1993 & 16.0 & 2.0 & 26.4 & 7 \\
\hline Zambia & 1995 & 17.5 & 2.6 & 32.3 & 2 \\
\hline
\end{tabular}


Table 2. VAT Collection Efficiency

\begin{tabular}{|c|c|c|c|c|c|c|}
\hline \multirow[b]{2}{*}{ Explanatory variables } & \multicolumn{3}{|c|}{ C-efficiency } & \multicolumn{3}{|c|}{ Efficiency } \\
\hline & $\mathrm{I}$ & II & III & IV & $\mathrm{V}$ & VI \\
\hline Real GDP per capita & $\begin{array}{r}1.682 \\
* * *(0.419)\end{array}$ & $\begin{array}{r}0.750 \\
* *(0.349)\end{array}$ & $\begin{array}{r}1.362 \\
* * *(0.427)\end{array}$ & $\begin{array}{r}0.974 \\
* * *(0.271)\end{array}$ & $\begin{array}{r}0.562 \\
* *(0.225)\end{array}$ & $\begin{array}{r}0.775 \\
* * *(0.277)\end{array}$ \\
\hline Agriculture share of GDP & $\begin{array}{r}-0.935 \\
* * *(0.189)\end{array}$ & $\begin{array}{r}-0.684 \\
* * *(0.196)\end{array}$ & $\begin{array}{r}-0.616 \\
* * *(0.197)\end{array}$ & $\begin{array}{r}-0.626 \\
* * *(0.122)\end{array}$ & $\begin{array}{r}-0.466 \\
* * *(0.127)\end{array}$ & $\begin{array}{r}-0.442 \\
* * *(0.128)\end{array}$ \\
\hline Trade openness & $\begin{array}{r}0.105 \\
* * *(0.040)\end{array}$ & $\begin{array}{r}0.104 \\
* * *(0.039)\end{array}$ & $\begin{array}{r}0.126 \\
* * *(0.040)\end{array}$ & $\begin{array}{r}0.042 \\
(0.026)\end{array}$ & $\begin{array}{r}0.046 \\
*(0.025)\end{array}$ & $\begin{array}{r}0.053 \\
* *(0.026)\end{array}$ \\
\hline Urbanization share of population & $\begin{array}{r}0.705 \\
* *(0.292)\end{array}$ & & $\begin{array}{r}0.703 \\
* *(0.286)\end{array}$ & $\begin{array}{r}0.251 \\
(0.189)\end{array}$ & & $\begin{array}{r}0.245 \\
(0.186)\end{array}$ \\
\hline Durability of political regime & & $\begin{array}{r}0.158 \\
* * *(0.058)\end{array}$ & $\begin{array}{r}0.143 \\
* *(0.058)\end{array}$ & & $\begin{array}{r}0.095 \\
* *(0.037)\end{array}$ & $\begin{array}{r}0.089 \\
* *(0.037)\end{array}$ \\
\hline Regulation of political participation & & $\begin{array}{r}2.593 \\
* * *(0.844) \\
\end{array}$ & $\begin{array}{r}2.774 \\
* * *(0.842)\end{array}$ & & $\begin{array}{r}1.486 \\
* * *(0.545) \\
\end{array}$ & $\begin{array}{r}1.549 \\
* * *(0.547)\end{array}$ \\
\hline Observations & 454 & 454 & 454 & 454 & 454 & 454 \\
\hline Number of country & 44 & 44 & 44 & 44 & 44 & 44 \\
\hline R-squared & 0.550 & 0.673 & 0.588 & 0.575 & 0.666 & 0.619 \\
\hline
\end{tabular}

Notes: The sample is an unbalanced panel covering 1970-1999. The method of estimation is fixed effects. All regressions include a constant and year dummies. Standard errors are in parentheses. $*, * *$, and $* * *$ denote significance levels at $10 \%, 5 \%$, and $1 \%$, respectively. 
Table 3. Robustness: VAT, years since it first implemented, and level of income

\begin{tabular}{|c|c|c|c|c|c|c|}
\hline \multirow{2}{*}{$\begin{array}{r}\text { Specification: } \\
\text { Dependent: }\end{array}$} & \multicolumn{2}{|c|}{ Adding Age of VAT } & \multicolumn{2}{|c|}{ High-Income Countries } & \multicolumn{2}{|c|}{ Developing Countries } \\
\hline & C-efficiency & Efficiency & C-efficiency & Efficiency & C-efficiency & Efficiency \\
\hline Explanatory variables & VII & VIII & IX & $\mathrm{X}$ & XI & XII \\
\hline Real GDP per capita & $\begin{array}{r}1.362 \\
* * *(0.427)\end{array}$ & $\begin{array}{r}0.775 \\
* * *(0.277)\end{array}$ & $\begin{array}{r}2.944 \\
* *(1.459)\end{array}$ & $\begin{array}{r}1.309 \\
(0.884)\end{array}$ & $\begin{array}{r}1.250 \\
* *(0.577)\end{array}$ & $\begin{array}{r}0.693 \\
*(0.382)\end{array}$ \\
\hline Agriculture share of GDP & $\begin{array}{r}-0.616 \\
* * *(0.197)\end{array}$ & $\begin{array}{r}-0.442 \\
* * *(0.128)\end{array}$ & $\begin{array}{r}-5.170 \\
* * *(1.929)\end{array}$ & $\begin{array}{r}-3.792 \\
* * *(1.169)\end{array}$ & $\begin{array}{r}-0.492 \\
* * *(0.166)\end{array}$ & $\begin{array}{r}-0.316 \\
* * *(0.110)\end{array}$ \\
\hline Trade openness & $\begin{array}{r}0.126 \\
* * *(0.040)\end{array}$ & $\begin{array}{r}0.053 \\
* *(0.026)\end{array}$ & $\begin{array}{r}0.090 \\
(0.205)\end{array}$ & $\begin{array}{r}-0.081 \\
(0.124)\end{array}$ & $\begin{array}{r}0.159 \\
* * *(0.034)\end{array}$ & $\begin{array}{r}0.085 \\
* * *(0.023)\end{array}$ \\
\hline Urbanization share of population & $\begin{array}{r}0.703 \\
* *(0.286)\end{array}$ & $\begin{array}{r}0.245 \\
(0.186)\end{array}$ & $\begin{array}{r}0.182 \\
(1.562)\end{array}$ & $\begin{array}{r}-0.522 \\
(0.946)\end{array}$ & $\begin{array}{r}0.891 \\
* * *(0.290)\end{array}$ & $\begin{array}{r}0.516 \\
* * *(0.192)\end{array}$ \\
\hline Durability of political regime & $\begin{array}{r}0.143 \\
* *(0.058)\end{array}$ & $\begin{array}{r}0.089 \\
* *(0.037)\end{array}$ & $\begin{array}{r}-1.323 \\
(0.960)\end{array}$ & $\begin{array}{r}-0.343 \\
(0.582)\end{array}$ & $\begin{array}{r}0.132 \\
* * *(0.048)\end{array}$ & $\begin{array}{r}0.076 \\
* *(0.032)\end{array}$ \\
\hline Regulation of political participation & $\begin{array}{r}2.774 \\
* * *(0.842)\end{array}$ & $\begin{array}{r}1.549 \\
* * *(0.547)\end{array}$ & $\begin{array}{r}0.000 \\
(0.000)\end{array}$ & $\begin{array}{r}0.000 \\
(0.000)\end{array}$ & $\begin{array}{r}2.892 \\
* * *(0.713)\end{array}$ & $\begin{array}{r}1.635 \\
* * *(0.472)\end{array}$ \\
\hline Years since VAT first implemented & $\begin{array}{r}-0.264 \\
(0.296)\end{array}$ & $\begin{array}{r}-0.006 \\
(0.192)\end{array}$ & & & & \\
\hline Observations & 454 & 454 & 116 & 116 & 338 & 338 \\
\hline Number of country & 44 & 44 & 9 & 9 & 35 & 35 \\
\hline R-squared & 0.589 & 0.619 & 0.139 & 0.065 & 0.188 & 0.221 \\
\hline
\end{tabular}

Notes: The sample is an unbalanced panel covering 1970-1999. The method of estimation is fixed effects. All regressions include a constant and year dummies. Standard errors are in parentheses. $*, * *$, and $* * *$ denote significance levels at $10 \%, 5 \%$, and $1 \%$, respectively. 
Table 4. Cross-Country VAT and Income Inequality

\begin{tabular}{|c|c|c|c|c|}
\hline Dependen & \multicolumn{2}{|c|}{ C-efficiency } & \multicolumn{2}{|c|}{ Efficiency } \\
\hline Explanatory variables & XIII & XIV & $\mathrm{XV}$ & XVI \\
\hline Real GDP per capita & $\begin{array}{r}2.755 \\
* * *(0.278)\end{array}$ & & $\begin{array}{r}1.584 \\
* * *(0.166)\end{array}$ & \\
\hline Agriculture share of GDP & & $\begin{array}{r}-0.998 \\
* * *(0.226)\end{array}$ & & $\begin{array}{r}-0.553 \\
* * *(0.136)\end{array}$ \\
\hline Durability of political regime & & $\begin{array}{r}0.311 \\
* * *(0.100)\end{array}$ & & $\begin{array}{r}0.183 \\
* * *(0.060)\end{array}$ \\
\hline GINI coefficient & & $\begin{array}{r}-0.415 \\
* *(0.192) \\
\end{array}$ & & $\begin{array}{r}-0.236 \\
* *(0.116) \\
\end{array}$ \\
\hline Number of country & 40 & 40 & 40 & 40 \\
\hline R-squared & 0.722 & 0.614 & 0.705 & 0.585 \\
\hline
\end{tabular}

Notes: The sample is a cross-country averages over the period 1970-1999. The method of estimation is OLS. Standard errors are in parentheses. ${ }^{*}, * *$, and $* * *$ denote significance levels at $10 \%, 5 \%$, and $1 \%$, respectively. 
Figure 1. Cross-country VAT revenues, 1970-1999

VAT revenue as a percentage of GDP
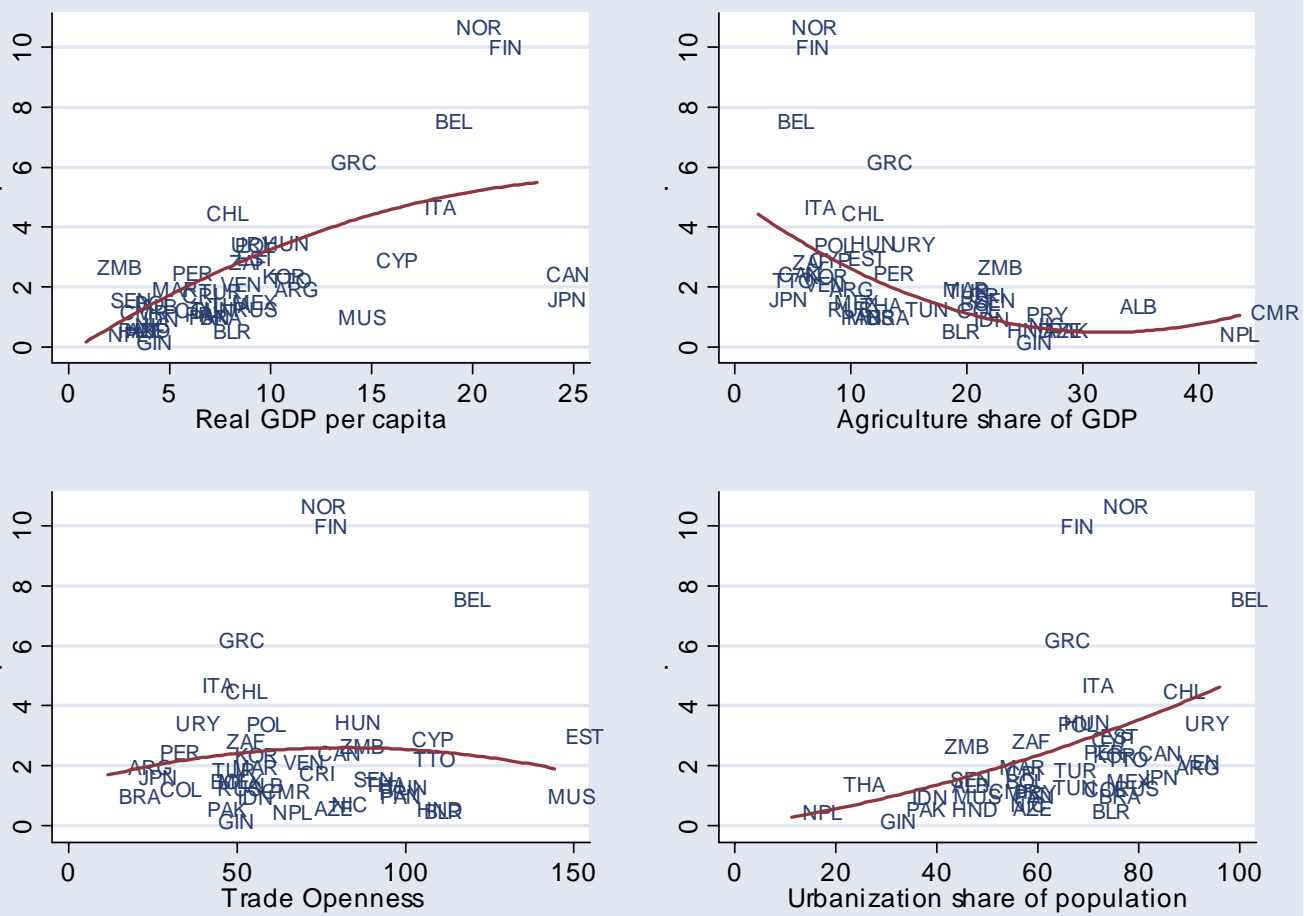

\section{VAT revenue as a percentage of total tax revenue}
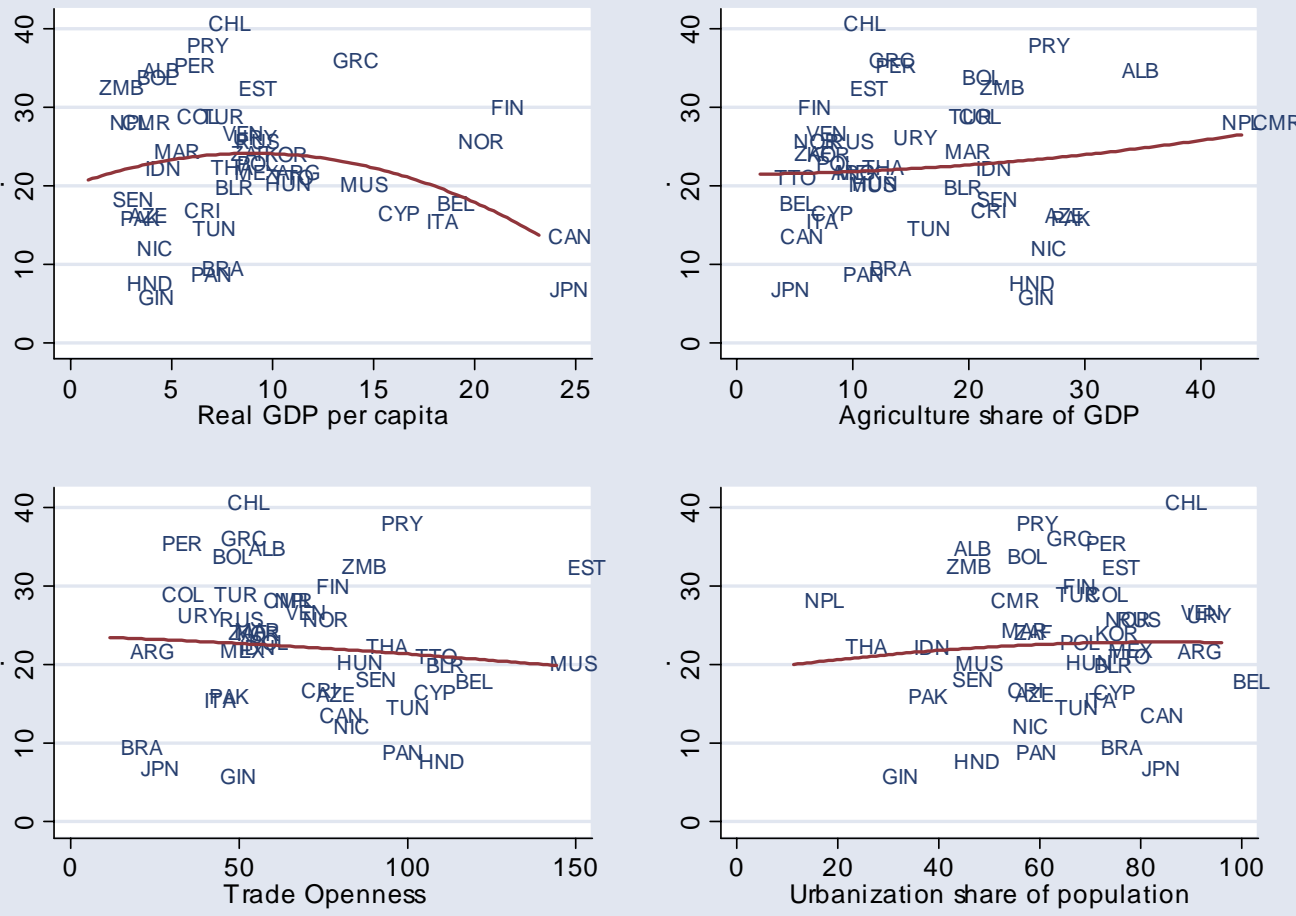
Figure 2. Effects of a one standard deviation change in explanatory variables

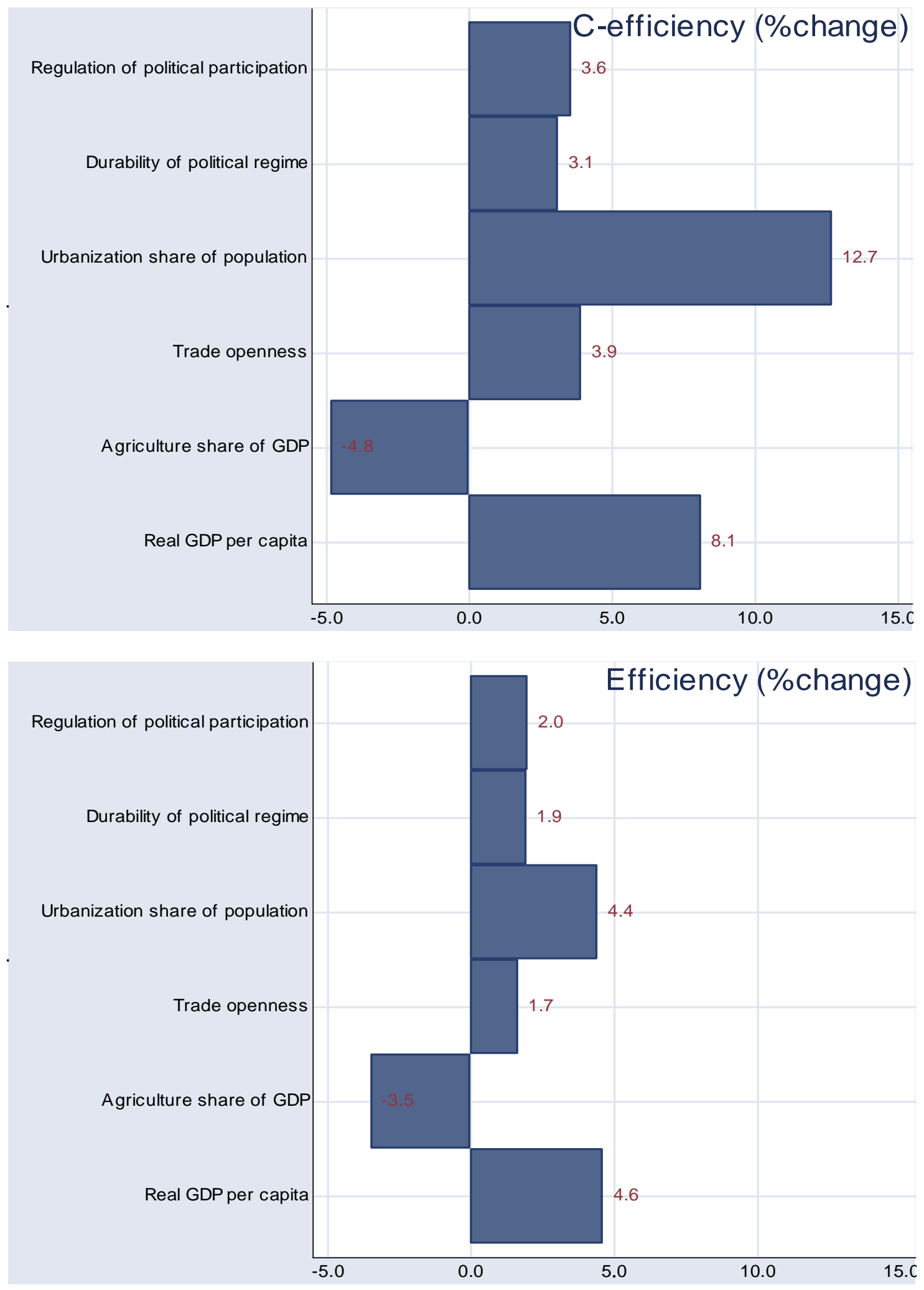

